\title{
The Application Of Integrated Quality Management In Education To Create Good Governance
}

\author{
$1^{\text {st }}$ Arie Supriati \\ Pancasila and Civic Education \\ Department \\ Universitas Negeri Manado \\ Tondano, Indonesia \\ ariesupriati@unima.ac.id \\ $4^{\text {th }}$ Maxi Ventje Keintjem \\ Pancasila and Civic Education \\ Department \\ Social Science Faculty \\ Universitas Negeri Manado \\ Tondano, Indonesia \\ maxikeintjem@unima.ac.id
}

\author{
$2^{\text {nd }}$ Sjamsi Pasandaran \\ Pancasila and Civic Education \\ Department \\ Universitas Negeri Manado \\ Tondano, Indonesia \\ $5^{\text {th }}$ Natanael F. Kaunang \\ Pancasila and Civic Education \\ Department \\ Social Science Faculty \\ Universitas Negeri Manado \\ Tondano, Indonesia \\ natanaelkaunang@unima.ac.id
}

\author{
$3^{\text {rd }}$ Julien Biringan \\ Departement of Pancasila dan Civics \\ Education \\ Faculty of Social Universitas Negeri \\ Manado \\ Manado, Sulawesi Utara \\ julienbiringan@unima.ac.id
}

\begin{abstract}
Research purpose is to study the application of management quality with the research object at SMKN 1 Airmadidi. The method that being used are descriptive qualitative method with data collection techqniue through observation, interview, and school records documentation. The result of this research shows that the application of quality management in SMKN 1 Airmadidi sufficiently optimal on emphazising in science, skills, and confidance. The application of quality management assured can support the realization of good education system in creating a good governance.
\end{abstract}

Keywords-Management, Quality of Education, Good Governance

\section{INTRODUCTION}

Education had really related with globalization. That is why Indonesia have performed reformation in educational process, with pressure to create more comprehensive and flexible educational system. Education had to be plan in such way to enabling the student can develop the potency that they have with artless and creative way in freedom, togetherness, and responsible environment. One of alternative way that can be done is that educational management in Indonesia with global insight. Government responded openly through Article 50 Clause 3 Laws Number. 202003 about National Educational System (NES Laws) that read: Government and/or Local Government perform at least one education unit in every educational stage to be develop as education unit with international standard. Based in legality principle this National Education System Laws provision, then outspreading various International Standard School (ISS) in every city/regency in Indonesia. Whereas in this matter education in Indonesia will facing some challanges like, the teacher has to perform a comprehensive study towards the occurring of reformation era and civil structure transformation, from traditional agrary society to modern industrial society also how the implication in enchancement and developing the quality of human resources life.

In global competition that getting fierce, education expected can increase nation competitiveness on creating creative works from the outcome of idea, inventions and science, technology, art mastership.

All of those challenges demand the existence of human resources with great quality and competitive with comprehensive and comparative with the insight of excellence, professional skills, ability to think about the future (visioneer), confidence and pride also with adequate skill compatible to the needs and market trade.

Based on the matter above, legality aspect is needed in about guarantee and educational quality enhancement including: (1) understanding and in the scope of guaranty and increasing the quality; (2) task disposal and responsibility that proportional in guarantee and eduaction quality enhancement, (3) National Education Standard achievement, and (4) developing education quality system that effective for managing, decision making in guarantee and educational quality enhancement.

Good Governance as public services that efficient, dependable justice system, responsible government for the public, social economy policy management that make sense, democratic decision making, governance transparency and adequate financial accountability, creating good environment in development, action to fight corruption, rule of law appreciation, Human Rights appreciation, press and expressive liberty. No exception on implementing a good and educational quality.

\section{RESEARCH METHODS}

This research designed with descriptive qualitative reseach just like opinion from Merriam (1) and would be more physical interaction with the people, location, or institution to observe or noted the behavior of the research background. This reseach put the researcher as key instrument, sample collecting that be performed in proportional and snowball way (2). Datat source in this research are third grade students and practice teacher in SMKN 1 Airmadidi. Data collecting date were done January until March 2018 with observation technique, in studying process at SMKN 1 Airmadidi. The informan were choosed 
by the researcher that belief to be capable enough to describe their experience, about total quality management application. Data collection procedure is trough profound and gradually interview, observation, documentation and records and interview results record with the informant with researcher. While data analisys tend to inductive/qualitative where the researcher performs an analisys to all research findings. This data analisys technique done with three activity stages, that is data reduction, data presentation, and making conclusion (3). The researcher performs data anlisys in qualitative way and in line with interview result and observation then data presentation in descriptive way.

\section{RESULT AND DISCUSSION}

As education institute SMKN 1 Airmadidi were perceptive with technology development. With the support of adequate the human resources the school are ready to compete with another school in public information services. Information technology especially Web, became the medium for SMKN 1 Airmadidi in providing fast, clear and accountable information. With the services, the school also ready to receive suggestion from all party that finaly an answer the society needs.

School vision is to create the school with character, have natural conservation and preserve insight also to produce professional graduate. Five school mission that all of them are intended to shape the student character in all sector.

" First to provide the student with knowledge and professional vocational skill and independent, Second developing natural knowledge implementation school, Third to braid partnership with the stakeholder and school quality development and graduate,"

"Fourth applied intergrated environment education in learning process, Fifth to applied natural conservation and preserve insight school culture," while the Motto of SMKN 1 Airmadidi is discipline, honest and hardwork.

SMKN1 Airmadidi applied performance assessment for public services unit that been executed by the north Minahasa regency government and Nation Apparatus Utilization and Reformation Beureau ministry (NAU-RB) Republic of Indonesia. The assessment of public services is really important, so that they can follow up the central government programe and that region. "SMKN 1 Airmadidi have 1.055 student and 43 permanent teachers also 20 nonpermanent teachers, that teach in some department that is: gastronomy, electricity, automotif, motorcycle, fashion design, and computer network. Posess MOU (Memorandum of Understanding) with 105 industries that scattered in north Celebes region and another region like in automotif section in Malang city, Gastronnomy in Bali and Yogjakarta an also Solo with fashion design. In 2017 SMKN 1 Airmadidi receive an "A" accreditation also holds the titled namely Independent Adi Wiyata School in SMK level.

School programe are organize formed in school education plan. All component tries to give comfort, full of togetherness also uphold national noble value, such as responsibility, discipline, and friendly to anyone. Total quality management implementation that already done by SMKN 1 Airmadidi. With that then the good governance on education in SMKN 1 Airmadidi can be reach well. Generally good governance contains some main element that is accountability, transparency, openness and rule of law. For the good governance can runs smoothly, it would come from all party. Wether it from the government, private and society in intending to achieve good governance that effective and efficient, equal, interpretation also work ethic and high morality that will be used as a fundamental value that has to be held by all component that related with good governance (4).

Good governance system can be achieved if theres a synergy between government, private and society in order to countinous development. However, the society had to be always critical to the government about the plan for the development.

Good governance is an effort to change the government face to not work alone without considering the importance or people aspiration. In the execution system that applied good governance (5). Education is important aspect that human had to fulfil to achieve the knowledge on how they live the life in this world in various sector of life.

In governmental section, education also have a big role in order to reach a good governance also known as Pemerintahan yang Baik, because education had a direct contact with society, that as a part of good governance domain and consist of three domains: education, teacher and learner, trough guidance activity, teaching for their role in the future time.

On long term, the manin agenda in effort to strengthen educational resources is to stengten the education system and educational resources that have skill.

The new skill is a human investmenr, and changes is needed on the learning system. Hani Handoko suggest that in $21^{\text {st }}$ century achievement of the skill needed for the learning system to be change because several reason: (1) the skill are needed to achieve success will be higer and rapidly change over time, (2) Skills that needed were realy depends on new technology and innovation, then many of that skill have to be improves and trained through training in work, and (3) the importance of the skill is based on individual skill (6). This all be done in order to create great synergy for the acceleration in human development index and to raise the competition of human resource on a globally scale.

To answer this challenge learning support needs to have skill, great competence, and have creative spirit also innovative. According to Nasution (2002), Total Quality Mangement- TQM (Manajemen Mutu Terpadu-MMT) as a fundamental value system and comprehensive in managing the organization at order to increasing countinous and longterm performance with offer special attention to reach customer satisfaction and complete regard about fulfillment the needs of all organization stakeholders that involved. The TQM quality issue damands all organization party to be involve and responsible (7).

TQM assumed to be an effoert to increase the quality of the product from all activity that occur in organization: that all the management function that available and all forces to participate in improvement process.

According to Nasution, Total Quality Management is an effort to optimize the organization in order for the custumer satisfaction. Therefore Total Quality Management related with: Focus to the customer, wheter internal or external customer; have a high obsession for the quality; using scientific approach in decision making and problem 
solving; had a longterm commitment; Teamwork are needed; countinous process repairmen; held education and training; providing controlled freedom; have similar purpose; theres employee involvement and empowerment.

On educational context, total quality management development, is a "services" business that provides services for their main customer namely those who learn (student) in an education institute. When all the preparation and strategy already applied then there is no need to worries about the invasion of foreign worker that will work her, because Indonesian human resouces especially from SMK graduate ready with a great competence. Moreover, if SMK graduate dominate the technology, competence spirited entrepreneur then it would be easy to change the world and be the master in their own nation, let the foreign worker to come to indonsia, we that will be the master who can manage it to become a big profit and strengthen nation competitiveness. Essentially the excellence human resources of educational context in Indonesia are people that armed with high intellectuality, good attitude and character also had great skill. Excellent human resouces implication need a long time and long process. But the principal thing is to gradually, slowly, continuous and organized well.

According to Sudarwan Danim, the education that we dreamt needed to be investigate some component that related with education process, especially the main component in building the future vision are: 1). Proper Curriculum with time evolution also be able to accommodate in latest world development. The dream curriculum is permanent curriculum, doesn't have to always be changed. The teacher feels more comfortable and not confuse with the curriculum. Because the curriculum will really be applied by the teacher through learning process. 2). Learning process, as an operational form of curriculum. The dream learning process is a fun learning process for teacher and student. Therefore, the purpose of learning process can be achieved and learning result can be owned and felt by the student. 3). Dream education facilitation including the falcilitation availability and teaching tool/material. With the facilitation that available will make the teacher passionate to teach, curriculum can be run as it should be, the learning process expected can be running effectively and efficient. 4). Students parent's participation. Education in school not only school and government responsibility. But student parent's participation also determines the succesfullnes of school in education development. 5). Dream education facilitation including the falcilitation availability and teaching tool/material. With the facilitation that available will make the teacher passionate to teach. In creating an exelent human resource quality, educational development strategy is needed. The government role not as mover, definer, and ruler in education, however the government should act as the catalysator, facilitator, and people empowerment. With information technology utilization in accessing information to improve self potential and environment (ex; internet using, multimedia learning, integrated information system, etc) (8).

SMK is a formal education that prioritize the development of student ability so that they can work in certain field, can adapt in work environment, notice a job opportunity, developing their career in the future come. The skills that have been prepared based on competence approach, so can be measured what competence that the student will achieve with jobs and practice as industrial needs. So that the ability that already been achived are pointed in Indonesia national job competence standar (INJCS) that already be setted by the government through manpower ministry.

In order for that realization, there is approach that had to be done, such as: (1) to make policies about the importance of education quality and (2) then to socialize the good governance in national scale (through integrated quality management guide in educational field). For that, SMK Negeri 1 Airmadidi already implied integrated quality management in order to enhance the aducation quality. That accelerated by the education and practice cooperate with the Ministry of Manpower and utilize Training center in many regions also trusted private institution to accommodate the needs to refresh and upgrade the compence from the SMK fresh graduate.

\section{CONCLUSION}

According from the explaination above, can be conclude that the learning process in SMKN 1 Airmadidi, already apply the integrated quality management in supporting good and excellent education. Indonesian human resources especially the SMK graduate ready with great competence. With the school mission that all of them is to shape the students' character to be great in all field. Good governance in education section gives the non-government party in this case the people can be optimaly involve and with synergy in developing the education quality. Some characteristic that attached in the application of good governance contained values that makes the government or education institutes can runs more effectively. The values like efficiency, justice and response became an important value in education, because the practice of good governance is governmental practice that clean and free from corruption also oriented with public interest that is the education customer. Can be conclude that good governance characteristic is the implementation integrated quality management that directed to achieve the national purpose in education field, when the government seem capable enough to create transparency, law enforcement, and public accountability (corresponding with the good governance principle), means that essentially the government implied intregrated quality management principle.

On developing the implication in of good governance, the government need to choose a proper strategy/method, because to be applied the good governance, required the government to take strategical option. The successfulness of good governance implication in public services can generate people trust to really be applied the good governance and became reality. The values that all this time characterize good governance implication like, efficient, non-discriminative, and fair, responsive, and great accountability can be develop easily. The government as representative of nation, civil society, and market mechanism, that all of them have the high importance and involvement in this field. With initiating the change in certain field that can really influence the people needs and customer (also known as stakeholders).

Another approach that need to be done is to do socialization, consultation, accompaniment for the related party or governmental office in order to implicate the good 
governance in education section, through activity, for example self assessment, and then set up signs in all institutes and regional government. With multiplying the agents of change for the quality by developing training for the public official and the education institute leader about this integrated quality management.

The characteristic of good governance in education field had to provide the opportunity for the non-government party especially society (customer) to optimaly act in order to create a synergy between them. Therefore, the civil society involvement is really important on applying the integrated quality management in educationto support the good governance manifestation.

\section{ACKNOWLEDGMENT}

The author would like to say thank Dean of Social Science Faculty Manado State University.

\section{REFERENCES}

1. Creswell JW. Research design: qualitative, quantitative and mixed approach. Yogyakarta: Student Library, 2010 pendekatan kualitatif, kuantitatif, dan mixed. Yogyakarta: Pustaka Pelajar; 2010.

Creswell JW. Research design: pendekatan kualitatif, kuantitatif, dan mixed. Yogyakarta: Pustaka Pelajar; 2010.

2. Sugiyono. qualitative, quantitative and $R \& D$ research Method. Bandung Alfabeta; 2008.

Sugiono. Metode Penelitian Kuantitatif, Kualitatif dan R\&D. Bandung: Alfabeta; 2008.
3. Sugiono P. Combined Research Method (Mixed Method). Bandung: Rosdakarya Teend; 2011

Sugiyono P. Metode Penelitian Kombinasi (Mixed Methods). Bandung: Remaja Rosdakarya; 2011.

4. Widodo J. Kepemerintahan yang Baik "Accountability and Birocration Control". Surabaya: Intellectual Human; 2001.

Widodo J. Good Governance "Akuntabilitas dan Kontrol Birokrasi”. Surabaya: Insan Cendekia; 2001.

5. Sedarmayanti. Kepemerintahan yang Baik (Good Governance) in order Regional autonomy creating the Effective and Efficient Organization through the Reconstruction and Empowerment. Bandung: Develop Mandar; 203 AD

Sedarmayanti. Good Governance (Kepemerintahan yang baik) dalam rangka Otonomi Daerah Upaya membangun Organisasi Efektif dan Efisien melalui Restrukturisasi dan Pemberdayaaan. Bandung: Mandar Maju; 203AD.

6. Handoko TH. Human Resources Management. Yogyakarta: BPFE; 2001.

Handoko TH. Manajemen Sumber Daya Manusia. Yogyakarta: BPFE; 2001.

7. Nasution MN. Integrated Quality Management. Jakarta: Fourth Salemba; 2005

Nasution MN. Manajemen mutu terpadu. Jakarta: Salemba Empat; 2005.

8. Sudarwan D. Education System Upgrade Agenda. Yogyakarta: Student Library; 2006.

Sudarwan D. Agenda pembaharuan sistem pendidikan. Yogyakarta: Pustaka Pelajar; 2006. 